\title{
Horthy Miklósról egy francia történész szemével
}

\author{
DOI: $10.1556 / 2065.179 .2018 .2 .16$
}

A 2014-es francia kiadás után, 2017-ben magyarul is megjelent a Kossuth Kiadó gondozásában Catherine Horel Horthy Miklósról szóló életrajza.

Az elmúlt évtizedekben Horthy Miklós fontos szereplöje volt a politikai, közéleti és a szakmai vitáknak. Születtek olyan életrajzok, amelyek egyoldalúan pozitívan, mások egyoldalúan negatívan ítélték meg a történelmi szerepét. Jelentek meg kiegyensúlyozottságra törekvő, Horthy tetteinek megértésére és nem a felmentésére vagy az elítélésére törekvő munkák is. Ide sorolható a Catherine Horel által írt életrajz is. Ezek a bevezető gondolatok elengedhetetlenek egy Horthy Miklósról szóló munka ismertetésekor, már csak azért is, mert egyrészt maga a szerző is hangsúlyt helyez arra, hogy bemutassa Horthy Miklós megítélésének változásait, ideértve annak a legaktuálisabb vonatkozásait, másrészt - már a kötet mottójával állást is foglal Horthy Miklós megítélésével kapcsolatban. A mottó Ludwig Windisch-Graetztől származik: „A történetírásnak az is feladata, hogy véget vessen a magyarok megalapozatlan Horthy-mítoszának.” A szerző tehát ezzel a mottóval kezdi munkáját, ezzel lehatárolva a könyv értelmezési lehetőségeit, így a munka funkciójává a Horthy-mítosszal szembeni fellépés válik. Emiatt a mai közéleti és politikai vitákra adott reflexiónak tekinthető ez a szakkönyv. A kitüzött célt a szerző úgy oldotta meg, hogy eközben nem azonosul a szélsőségesen negatív Horthy Miklós értelmezésekkel, amelyeket szintén megalapozatlannak tekint. Catherine Horel Horthyképe összességében inkább kritikus, azonban kiegyensúlyozottságra és megértésre törekvő.

A könyv három nagy egységre oszlik: A tengerész (1868-1918), A kormányzó (1919-1944) és A számüzött (1944-1957). Catherine Horel írta az első olyan tudományos igényességü, jegyzetekkel ellátott életrajzi nagymonográfiát, amely Horthy Miklós életének egészével foglalkozik. (Thomas Sakmyster monográfiája az 1918-1944 közötti időszakra koncentrál.) A kötet arányaiból azonban látszik, hogy a hangsúly ebben az életrajzban is az 1919-1944 közötti időszakra helyeződik (202 oldal), míg az 1882 és 1918 között időszak, a haditengerészeti pályafutása 46 oldal, az emigráns évei, az 1944 és 1957 közötti periódus pedig 30 oldal terjedelmet kap. A Horthy Miklós utóéletéről és emlékezetéről szóló fejezet 20 oldal.

Az 1868 és 1918 közötti időszakot bemutató fejezetben a szerző időrendi sorrendben mutatja be Horthy karrierjének egyes állomásait, kiemelve például a világ körüli útját, illetve a szárnysegédi szolgálatát és az első világháború időszakát, tehát a csomópontokat, kitérve azok jelentőségére, képzettségének, tapasztalatainak és kapcsolati hálójának bővülésére. Nem feledkezik meg a szerző Horthy Miklós magánéletének alakulásáról sem, amely szintén jelentős hangsúlyt kap a kötetben. A szerző az 1918-as összeomlás kapcsán hangsúlyozza a Monarchiával teljes mértékben azonosuló Horthy Miklós életpályáján belül ennek az időszaknak a kiemelt szerepét.

A könyv gerincét alkotó, az 1919 és 1944 közötti időszakot bemutató rész hét alfejezetre oszlik. A gondviselés embere címü alfejezet - az 1918-1919-es eseményeket bemutató alfejezetet követően - a korszak elejét tárgyalja. Ebben a politikatörténet áttekintése során már kirajzolódik az államföi portré több eleme is, tehát - a kötet elöszava után - részletesebb képet kap az olvasó arról, hogyan is látja, értékeli a szerző Horthy Miklós politikai szerepét. E portré egyik meghatározó eleme az antibolsevizmus, a másik az antiszemitizmus, amely összekapcsolódott az előzővel. Nagy hangsúlyt fektet a szerző a korabeli propaganda bemutatására a későbbi fejezetekben is, ami érthető, hiszen a kötet célja a mai - a két világháború közötti időszakból is táplálkozó - Horthy-mítosz megalapozatlanságának igazolása. A kormányzó és a király: a restauráció kérdése címü alfejezet az 1921-es történéseket taglalja, összefoglalja a közismert eseményeket. Horthy szerepét illetően azt 
olvashatjuk, hogy a legitimisták és a szabad királyválasztók között őrlődik, majd amikor döntenie kellett a „személyes ambíciója, hiúsága és hatalomvágya” vált döntővé (114.). Ezzel Horel szerint Horthy meghozta „élete utolsó meghatározó döntését” (13.).

A harmadik alfejezetet követően megszakad a kronologikus tárgyalásmód, ugyanis két tematikus fejezet következik. A Horthy-rendszer címü fejezet a Horthy-korszak egyes aspektusairól szól: például a társadalomról; a gazdaságról; a politikai rendszer jellegéről, a korszakot jellemző szimbolikus politikáról, főként az irredentizmusról; és a külpolitikáról. Horthy Miklósról viszonylag kevés szó esik ebben a fejezetben. Horthy élete mellett tehát hangsúlyos a korszak bemutatása is. Ez azonban úgy valósul meg (a kötetben máshol is), hogy Horthy Miklós több esetben is elveszik a köztörténetben, azaz az életrajz és a köztörténet nem minden esetben van egymással megfelelö arányban. Az ezt követő fejezet, A kormányzó és az ö királysága címmel, két témával foglalkozik: a Horthy családdal és Horthy Miklós - a szerző szóhasználata szerinti - „,személyi kultuszával”. A kormányzói családról szóló rész a kötetnek a kormányzó magánéletére vonatkozó részét erősíti. Megismerhetjük a kormányzó napirendjét, feleségének szerepét (a férjére gyakorolt befolyását), a gyermekeiknek magánéletét és karrierjét, és Horthy István kapcsán az utódlás problematikáját. Az utódlás hátterében a kormányzó kora, a háborús nemzetközi körülmények és ,a hatalom megőrzésének szándéka” húzódott meg a szerző szerint (192.), majd István halála „véget vet a dinasztia születésére vonatkozó számítgatásoknak” (195.). A „személyi kultusz” esetében a szerző viszonyítási pontját a korabeli totalitárius rendszerek jelentik, így ebben a keretben elemzi a kultuszépítést szolgáló propaganda fontosabb megnyilvánulási formáit, kiemelve a fejezet végén a kormányzó hivatalos látogatásait és a külföldi vendégek fogadását, mint „a személyi kultusz megannyi ünnepi pillanatát" (212.).

A kronologikus tárgyalásmódhoz az 1936 és 1944 közötti időszak bemutatásakor, a Fogaskerekek között címü alfejezetben tér vissza a szerző. Az 1936 és 1942 közötti periódus áttekintése során, a köztörténetbe ágyazva a kormányzó jellemzésekor a hibáiról, a tétovázásáról, a határozatlanságáról olvashatunk, arról, hogy „,rosszul választ meg embereket, ami idővel katasztrofálisnak bizonyul" (223.). A külpolitikai folyamatok bemutatásakor, ebben kitérve Horthy szerepére is, az ország mozgásterének szükülését érzékeltetendő a szerző a „fogaskerékrendszer” kifejezést használja, amely „háborúba sodorja Magyarországot” (243.). Egyszerre jelenik meg az egyéni, a kormányzói felelősség és a nemzetközi erőviszonyok szerepe. A végjáték címü, az 1944-es eseményekkel foglalkozó alfejezet jobban kiemeli a kormányzó szerepét, mint az előző. A kötelességtudata által motivált, az államfői hivataláról le nem mondó és a megszállás után „kétségbeesett” (265.) kormányzó portréja rajzolódik ki, aki - a szerző szerint - július elején ,ébredt fel” (268.), és állíttatta le a deportálásokat.

A szerző az 1944 őszi átállási kísérlet bemutatásáig - a római, vatikáni és párizsi levéltári kutatásait leszámítva - alapvetően ismert adatokat, tényeket foglal össze, elemez és mutat be olyan források alapján, amelyeket a történeti kutatások során más történészek már használtak. Az emigráció éveivel kapcsolatos ismereteinket Horel lisszaboni és berni kutatásai egészítik ki, és pontosítják több esetben is, például a Portugáliába költözés körülményeit.

Azt követően, hogy a rendszerváltozást követő időszakra koncentrálva, a Horthy utóélete címü fejezetben a szerző bemutatja Horthy Miklós megítélését, Catherine Horel összegzi a könyvének lényegi üzenetét. Eszerint Horthy élete ,győzelemnek álcázott bukások hosszú sorozata" volt (330.), amely értékelés összhangban van a kötet mottójával.

(Catherine Horel: Horthy. [History Könyvek sorozat] Budapest: Kossuth Kiadó, 2017, 384 o.)

Turbucz Dávid

$\mathrm{PhD}$, tudományos munkatárs

MTA Bölcsészettudományi Kutatóközpont Történettudományi Intézet 